\title{
Floods and Rainstorms Impacts, Responses and Coping Among Households in Ilorin, Kwara State
}

\author{
Olorunfemi, F.B and Raheem, U.A \\ ${ }^{1}$ Nigerian Institute of Social and Economic Research, Ibadan, Nigeria. \\ ${ }^{2}$ Department of Geography, University of Ilorin, Ilorin, Nigeria.
}

\section{Doi:10.5901/jesr.2013.v3n4p135}

\begin{abstract}
Floods and rainstorms affect households each year in llorin and contribute to endemic poverty among the poor households in the city. Climate change and anticipated increases in extreme weather events will exacerbate this. This study examines the impacts of flooding and rainstorms in the city and the current responses and coping among the affected households. The social risk management (SRM) and asset-based approaches on which the study is based provide a conceptual framework for understanding the sequential links between risks; human exposure and sensitivity; the impacts of risky events; and risk management (or adaptation) strategies. Both primary and secondary data were used for the study. The secondary data include data from the Kwara State Emergency Management Agency (KSEMA) on flood victims in the State between 2007 and 2009 while the primary data is a structured questionnaire administered to flood and rainstorm victims randomly selected from the KSEMA records. This study brings out the important issue of vulnerability, coping and adaptation to weather induced disasters among the urban poor. A Multiple linear regression model tested shows that the house characteristics and neighbourhood quality contribute significantly to vulnerability to rainstorm and flooding. The study revealed that the indigenous coping mechanisms employed by the poor may become less effective as increasingly fragile livelihood systems struggle to withstand disaster shocks. Strategies to reduce vulnerability should be rooted in vulnerability analysis and greater understanding of both household-level and macro-response options that are available to decrease the poor's exposure to climate risk.
\end{abstract}

Keywords: Climate change adaptation, Disasters, Flooding, Vulnerability, Poverty.

\section{Introduction}

Disaster risk and climate change are two threats to human well-being that reinforce each other. Hence, they represent some of the greatest challenges to humankind in this century. Disaster risk is an intrinsic characteristic of human society, arising from the combination of natural and human factors and subject to exacerbation or reduction by human agency. While the adverse impacts of climate change on society may increase disaster risk, disasters themselves erode environmental and social resilience, and thus increase vulnerability to climate change (O'Brien et al, 2008, Gbadegesin et al, 2011). Climate change - and the likely increase in disasters - threatens to block pathways out of poverty in developing countries especially those in Africa (Lemons and Tompkins, 2008) Any increase in disasters, whether large or small, will threaten development gains and hinder the implementation of the Millennium Development Goals (ISDR, 2008).

In the coming decades, climate change is expected to exacerbate the risks of disasters, not only from more frequent and intense hazard events but also through greater vulnerability to the existing hazards (ISDR, 2008). Approaches toward the management of climate change impacts 
have to consider the reduction of human vulnerability under changing levels of risk. A key challenge and opportunity therefore lies in building a bridge between current disaster risk management efforts aimed at reducing vulnerabilities to extreme events and efforts to promote climate change adaptation (Olorunfemi, 2008, Few et al. 2006)

The long term horizon of climate change and current scientific uncertainties pose special challenges. Strategies that address challenges recognise that there is no best solution. In this sense, climate change provides new incentives for the need to plan ahead and to anticipate extreme events and trends (Zevenbergen, et al, 2008). Within the context of extreme weather events especially flooding, this means that management strategies must meet the present needs while providing a path of adjustment for the future (Pahl-Wosll, 2006; Ashley et al., 2007; Miller, 2007).

Cities in developing countries are particularly vulnerable to climate change impacts, especially changes in rainfall (Vogel 2000), because of the exposure to extreme weather events and dependence on natural resources (Vogel, 2002). The vulnerability situation, the present and predicted impact of climate change on urban areas is particularly worrisome. According to Satterhwaite et al (2007), the scale of the devastation to urban populations and economies caused by extreme weather events in recent years highlights their vulnerabilities. Worldwide, there has been a rapid growth in the number of people killed or seriously impacted by storms and floods and also in the amount of economic damage caused; a large and growing proportion of these impacts are in urban areas in low- and middle-income nations. For instance, in Nigeria, flooding affected more than three million people in selected urban areas between 1983 and 2009 (EMDAT disaster database). Climate change is likely to have been a factor in much of this, but even if it was not, it is proof of the vulnerability of urban populations to floods and storms whose frequency and intensity climate change is likely to increase in most places.

Henderson (2004) revealed that the level of risk and vulnerability in urban areas of developing countries is attributable to socio-economic stress, aging and inadequate physical infrastructure. Indeed, according to Satterthwaite et al (2007), hundreds of millions of urban dwellers have no allweather roads, no piped water supplies, no drains and no electricity supplies; they live in poorquality homes on illegally occupied or sub-divided land, which inhibits any investment in more resilient buildings and often prevents infrastructure and service provision. A high proportion of this are tenants, with very limited capacities to pay for housing - and their landlords have no incentive to invest in better-quality buildings. Most low-income urban dwellers face serious constraints in any possibility of moving to less dangerous sites, because of their need to be close to income-earning opportunities and because of the lack of alternative, well-located, safer sites. Nigerian urban areas are typical examples of this high level of risk and vulnerability (Olorunfemi, 2008; Olorunfemi and Raheem, 2007).

Successful national economies depend on well-functioning and resilient urban centres. Urgent action is needed now both to address urban centres' current vulnerabilities to extreme weather and to build into expanding urban centres protection from likely future changes (Satterthwaite et al, 2007). For most prosperous and well-governed cities, adaptation to the likely risks from climate change for the next few decades does not appear problematic. This centres on adapting buildings and infrastructure to the increasing risks; working with population groups and settlements most at risk to find solutions that serve them; and good disaster preparedness. But in developing countries, you cannot adapt infrastructure that is not there. The vulnerability of low-income urban dwellers to climate change is often ascribed to their poverty - but it is far more the result of failures or limitations in local government that ensure needed infrastructure is in place.

To date, the challenge of addressing urban floods and reducing urban flood vulnerability has received little attention (Zevenbergen, 2008). This is partly because in the traditional flood management approach, responses to mitigate urban fluvial and coastal flood risks have often been set outside the realm of the urban system (i.e. where confined to the catchment level), but also because responses at the city level were predominantly passive, using robust solutions such as 
urban defences and increasing the capacity of major culverts. The following major bottlenecks have been identified, which hamper the adoption and effective implementation of flood-risk management in urban planning practices (Sz" oll"osi-nagy \& Zevenbergen, 2005):

(i) Lack of understanding of current and future risks and implications at the city scale.

(ii) Lack of long-term planning, poorly integrated and comprehensive planning.

(iii) Inadequate controlling roles of local and regional authorities, and the conservative nature of the building sector.

While examining city development with particular reference to growth of slums and the impacts of climate change on inhabitants of four selected urban poor communities along the coast of Lagos (Makoko, Ilaje, Ijora-Oloye and Marine Beach-Apapa), Adelekan (2009) revealed that flooding is perceived the most important problem among surveyed communities. From a list of problems encountered in the communities, flooding was ranked as the foremost problem. Other problems mentioned are bad roads, pollution, and infestation by mosquitoes, neighbourhood insecurity, poor power supply, unemployment and prevalence of diseases (Adelekan 2009). The interviewees highlighted several causes for flooding such as overpopulation of the communities, inadequate drainage system, increase in water level of lagoon, overflowing of rivers, blockage of canals due to improper waste disposal, sand filling activities in communities, neglect by government, and supernatural factors (Adelekan 2009).

Extreme weather events especially floods and rainstorms affect households each year in the city of Ilorin affecting the poorest and most vulnerable people in the city and contributing to endemic poverty in most parts of Kwara State. This study, therefore, focuses on the impacts and adaptation to these events city. The specific focus is on the people living in the poor, marginal areas. The study is driven by the underlying assumption that human vulnerability to natural disaster and, particularly, those expected to be amplified by climate change, illustrates the interrelatedness of governance and environment related issues. Central questions are what generates vulnerabilities and what improves resilience in people's livelihoods, and how can we build on people's own responses, providing a range of institutional support, and promoting resilience and adaptive capacity among vulnerable people in the affected areas. The study supports the emerging view that places adaptation to shocks associated with climate change as a subset of disaster risk reduction.

The paper is divided into six sections. Following this introductory section is the conceptual framework that guided the conduct of the study. The third section provides a description of the study area followed by the methodology of the study in the fourth section. The fifth section, divided into different sub-sections, discusses the findings of the study. The conclusions of the study are presented in the last section.

\section{Conceptual Framework}

Urban environments are complex - socially, economically and physically. This complexity multiplies the risk which comes from increasing poverty and inequality and failures in governance, high population density, crowded living conditions and the siting of residential areas close to hazardous industry or in places exposed to natural hazard (including the modification of environments which generates new hazard, e.g. through the loss of protective mangroves to urban development, or subsidence following ground water extraction) (Pelling, 2008). This, combined with the cumulative nature of many environmental problems, makes it difficult to identify causal relationships when considering risk and vulnerability (Oelofse, 2002). Urban risk and vulnerability need to be understood in terms of the nature of risk, the causal mechanisms that shape people's response to them and the contingent conditions that provide the context within which they occur. Many risk problems sit at the interface of the natural and social environment, such as flooding, which occurs as the result of the inadequate provision and maintenance of drainage systems, the location of people on marginal sites, and the physical characteristics of an area (Oelofse, 2002). 
This study adopts the framework developed by Heltberg et al, (2008). The framework presents and applies the social risk management and asset-based approaches to the context of climate change. The social risk management (SRM) and asset-based approaches provide a conceptual framework for understanding the sequential links between risks; human exposure and sensitivity; the impacts of risky events; and risk management (or adaptation) strategies. This provides a unifying conceptual framework to examine the characteristics of the risks faced by households; how adaptation responses at multiple levels depend on livelihoods, policies, and institutions; and household vulnerability outcomes. It highlights the importance of a multidimensional and equitable approach to adaptation policy and the need to include higher level (national and international) risk management interventions. This includes social policy and social protection interventions to build resilience at the household level through improved human and physical capital and access to risk management instruments such as safety nets and insurance.

This analytical framework helps focus on the sequential links between climate risks, human vulnerability, and interventions to help manage vulnerability to climate change. The framework is consistent with IPCC (2001) definitions of vulnerability and adaptation and highlights that:

1) All households and individuals face risks associated with climate change, but not all are vulnerable. Vulnerability is a function of risks, exposure and sensitivity and adaptive capacity, and depends on the relationship between losses and some benchmark indicator of household well-being (e.g., a poverty line).

2) The exposure and sensitivity of household assets and livelihoods to climate change and their adaptive capacity are to a large extent shaped by policies and investments outside of their direct control.

3) Risks related to climate change can impact household assets, livelihoods and well-being directly and indirectly, so a multi-dimensional approach to risk management is required.

4) Ex-ante management of climate related risks, especially those that lower exposure and sensitivity of assets and livelihoods, can strengthen household assets and increase returns on assets, thereby contributing to improved livelihoods and well-being.

5) Climate risk management (or adaptation) has to be multidimensional and span interventions at household, community, national, and (increasingly) international level.

6) Institutions and good governance are keys to a multidimensional and multisectoral approach to improved adaptation to climate change.

Thus, household livelihoods and well-being depend on the interface between assets (broadly defined), the policy and institutional context, and risks (Figure 1). Risk affects the expected returns and variance of returns on assets and livelihood strategies, and therefore household well-being and future asset accumulation. Households are poor because they have limited quantity and quality of assets; and their assets have low expected returns and high variance of returns. The combination and flexibility of assets also matters: Poor and vulnerable households tend to lack key assets and whatever assets they have are not mobile and of poor quality and location. Many poor rural households are also landless and depend on selling their labour, which is typically of low quality in terms of education, skills, and health and nutritional status. Furthermore, because of gender, class, or caste, some individuals and households can have limited access to markets and livelihood opportunities, including migration. This, in turn, limits labour productivity and returns to human assets.

\section{Figure 1: Schematic Presentation of Asset-Based Approach}

\begin{tabular}{|c|c|c|c|c|}
\hline \multicolumn{3}{|c|}{ Household Assets } & \multicolumn{2}{|c|}{ Policy and Institutional Context } \\
\hline Productive & $\begin{array}{l}\text { Social and } \\
\text { Political }\end{array}$ & Locational & $\begin{array}{l}\text { Community and } \\
\text { Local }\end{array}$ & $\begin{array}{l}\text { National and } \\
\text { Global }\end{array}$ \\
\hline Human & $\begin{array}{l}\text { Social } \\
\text { Networks }\end{array}$ & $\begin{array}{l}\text { Agro-Ecological } \\
\text { Zone }\end{array}$ & $\begin{array}{l}\text { Community and } \\
\text { Local Institutions }\end{array}$ & $\begin{array}{l}\text { Government and } \\
\text { Governance }\end{array}$ \\
\hline
\end{tabular}




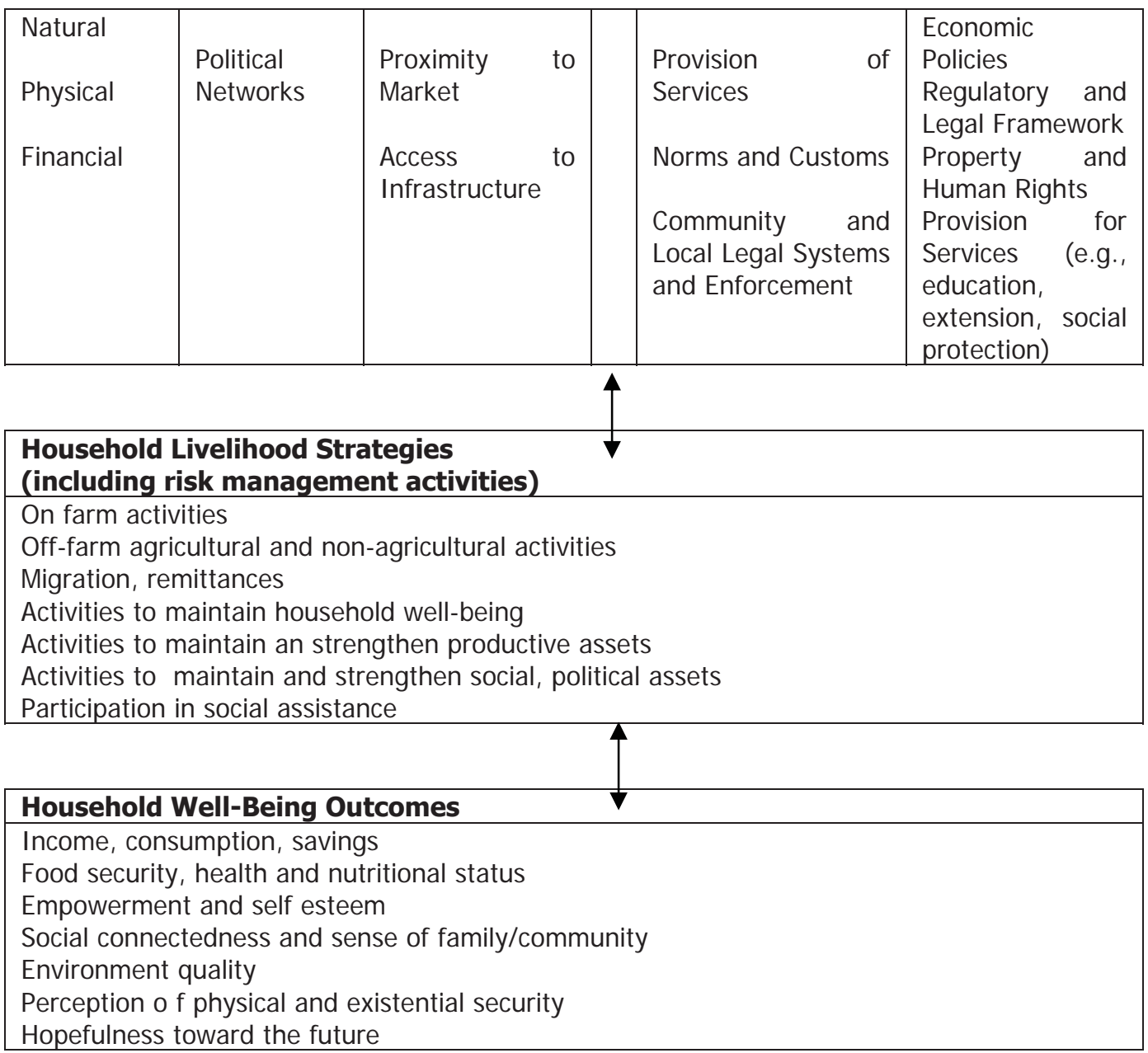

Source: Heltberg et al, 2008

\section{The Study Area}

Ilorin, the capital city of Kwara State, Nigeria, is the setting for this study. The city is located on latitude $8^{0} 10^{\prime} \mathrm{N}$ and longitude $4^{0} 35^{\prime} \mathrm{E}$ marking a divide between the southern forest Zone and the Northern grassland of Nigeria. The vegetation, in most parts, is guinea savanna interspersed by trees of different species. The dominant streams are Asa, Aluko, Okun, Amule, and Agba. The Asa River is of particular influence on the direction of growth of the city. The situation of the city between the dry North and the wet South of Nigeria gave Ilorin the apt description as the "gate way" between the North and the South of the country" (Adedibu, 1980). The climate is therefore tropical wet and dry characterized by a distinct wet and dry seasons. The mean annual temperature is about $26.80^{\circ} \mathrm{C}$ with five hours average daily sunshine. The mean annual rainfall is about $125 \mathrm{~mm}$. It is important to note that the above locational and physiographic characteristics possess (sometimes significant) implications for human health on one hand and economic and social development on the other.

Ilorin is a typical traditional African city whose urban history predates colonialism in Nigeria. The city therefore falls into the category of third world cities described as reputed for their dualistic 
internal structure (Mabogunje, 1968). The physical development of Ilorin also translates into significant change in the population of the city. For instance, from 36,300 inhabitants in 1911, Ilorin has a population of about 208,546 in 1963, 532,088 people in 1991 and a projected population of about 765,791 by the year 2006 at the rate of $2.84 \%$ annually. The facts of urbanization, development of the modern commercial/industrial economy and the multiplier effects of these factors on natural increase had combined to produce the changes in population described above. Figure 2 is a map of Kwara State showing Ilorin.

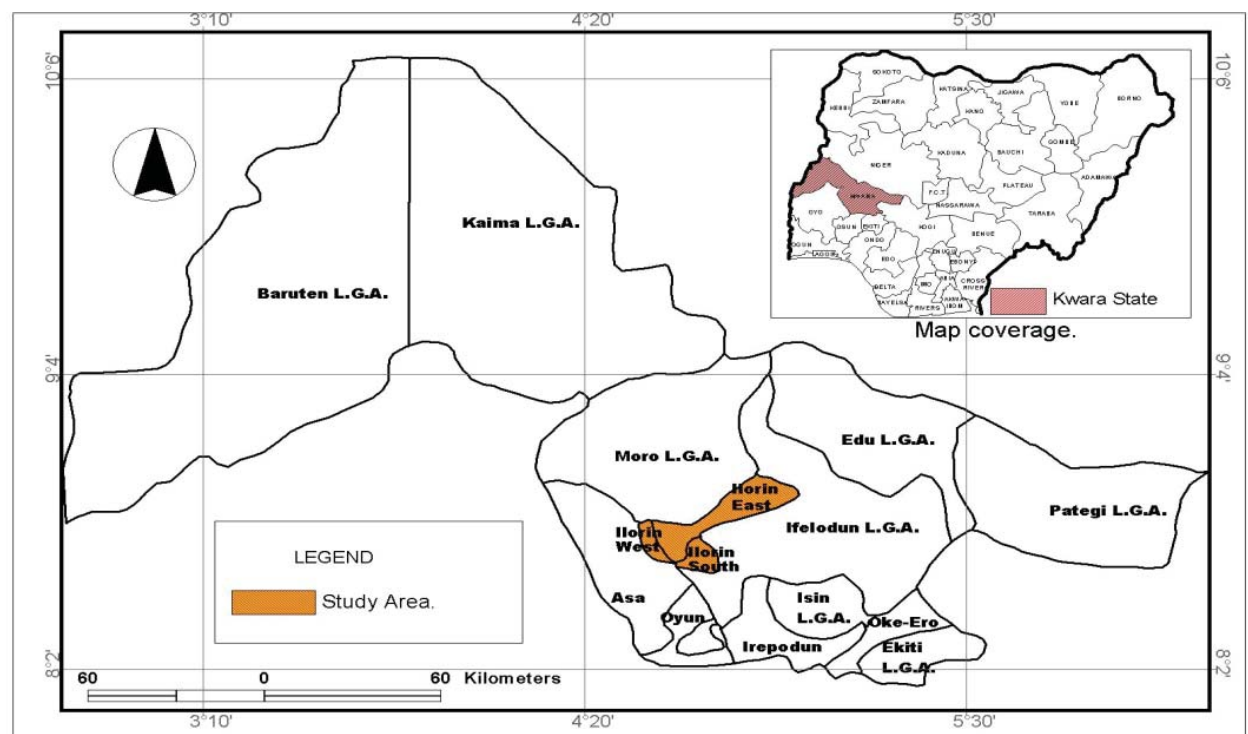

Fig.2: Map of Kwara State showing the Study Area (Inset: Map of Nigeria).

Frequent rainstorms and flooding in Ilorin has made it one of the most vulnerable cities in Nigeria in the recent past. The number of such incidents has been on the increase in the last few years. As shown in Table 1, apart from the fact that the number of incidents have increased, so also has the severity which translates into extensive damage to properties and the livelihoods of the people.

Table 1: Rainstorm and Flooding Incidents in Ilorin, 2002-2007

\begin{tabular}{lll}
\hline Year & Rainstorm/Flooding Incidents & Severity* \\
\hline 2002 & 4 & High \\
2003 & 2 & Moderate \\
2004 & 4 & Moderate \\
2005 & 6 & High \\
2006 & 6 & High \\
2007 & 8 & High \\
2008 & 7 & High \\
\hline
\end{tabular}

* Severity in terms of number of people affected and economic losses

Source: Kwara State Emergency Management Agency's records

\section{Data and Methods}

In order to study the vulnerability and adaptation of flood victims in Ilorin, the study utilized both primary and secondary data. The secondary data were collected mainly from the National 
Emergency Management Agency, Kwara State office. The data collected include those on rainstorm and flooding between 2007 and 2009. A record of about 1115 houses was affected by various these incidents during this period. Aside this, data were collected form households that occupied the properties destroyed by rainstorms and floods during the period under review. Thus, a total of 110 households were sampled, representing approximately $10 \%$ of the total number of households that were located during the preliminary survey.

A structured questionnaire was administered to them in addition to oral interviews and on the spot assessment of the victims' houses to determine the extent of damage to properties. The questionnaire elicited information on the socio-economic characteristics of the victims, their opinion of government handing of the situation, their coping mechanisms with the disaster incidents as well as their adaptation measures. The questionnaire also elicits information on how the disaster affected their livelihood systems. Furthermore, the victims were asked about their perception of the causes of frequent rainstorms and flooding incidents, and their understanding of climate changes issues. Data were collected on the characteristics of the victims' houses and neighbourhood characteristics.

Ilorin is traditionally divided into 4 socio-cultural and economic areas namely, the estates, inner city, frontier native areas and the suburban. These areas are further subdivided into 20 wards. Using the data obtained from NEMA in respect of the number of buildings affected by rainstorm and flooding, the data was organized according to wards from where a map was used to show the spatial variation in flooding/rainstorm severity among the wards (see Figure 3 ). Furthermore, a multiple linear regression model was tested to see the determinants of the vulnerability of houses to rainstorm and flooding. Specifically, the model was designed to see how housing and neighbourhood characteristics determined the impacts of rainstorm and flooding on houses. The dependent variable was represented by the number of houses affected by rainstorm and flooding. The independent variables used for the model were the characteristics of the buildings such as age, materials for the wall and the roof etc (these constitute the house quality). Apart from house characteristics, neighbourhood attributes were also used. The neighbourhood attributes were aggregated into one variable called the neighbourhood quality index. Neighbourhood quality index (NQI) was derived from composite of variables which include presence or absence of tarred roads, drainage, solid waste collection system, green areas, odour, health facilities, and pipe borne water. Where a variable is available it is 1 and otherwise 0 .

The model was then formulated as follows:

\section{NHD $(Y)=b_{1}(H T T)+b_{2}(H C B)+b X_{3}(H I R)+b_{4}(D T) b_{5}(N Q)$}

Where:

$Y(N H D)$ Number of houses destroyed

$\mathrm{X}_{1}$ (HTT) Number of houses older than 20 years

$\mathrm{X}_{2}$ (HCB) Number of houses constructed with materials other than concrete blocks

$X_{3}$ (HIR) Number of houses with inferior roofs

$\mathrm{X}_{4}$ (DT) Dwelling type

$X_{5}$ (NQI) Neighbourhood quality

\section{Results and Discussions}

\subsection{Socio-Economic Characteristics of Respondents}

The results of the analyses provided in Table 2 shows that males constituted the highest percentage of respondents $(74.6 \%)$. This is not surprising considering the fact that most households in the city are male headed due largely to socio-cultural and religious factors. More than two thirds of those interviewed are married (86.4\%). Also, more than two thirds are above 36 
years of age. Specifically, the largest proportions of the respondents (40\%) are above 50 years of age. Again, this is not surprising considering the fact that most of the inhabitants of the core/indigenous areas which are often mostly affected by flooding/rainstorm are old people. With respect to the level of education obtained, $16.4 \%$ have no formal education while only $14.6 \%$ have tertiary education. Most of the respondents are artisans (38.2\%), 28.2\% farmers and another $20 \%$ are traders. It is clear from the results that only $9.1 \%$ of the respondents are engaged in the formal sector. With respect to the household size, close to $80 \%$ of the respondents have more than 4 people in the household.

Table 2: Socio-Economic Characteristics of Respondents

\begin{tabular}{llll}
\hline Socio-economic Characteristics & Frequency & Percentage \\
\hline Sex & Male & 82 & 74.6 \\
Age & Female & 28 & 25.5 \\
& 20 and below & - & - \\
& $21-35$ & 28 & 25.5 \\
Marital status & $36-50$ & 38 & 34.6 \\
& Above 50 & 44 & 40.0 \\
Education & Single & 9 & 8.2 \\
& Married & 95 & 86.4 \\
& Others & 6 & 5.5 \\
Occupation & No formal education & 18 & 16.4 \\
& Primary & 36 & 32.8 \\
& Secondary & 40 & 36.4 \\
& Tertiary & 16 & 14.6 \\
& Civil servants & 10 & 9.1 \\
& Farming & 31 & 28.2 \\
Household size & Artisan & 42 & 38.2 \\
& Trading & 22 & 20.0 \\
& Unemployment/retired & 5 & 4.6 \\
& $1-3$ & 27 & 24.6 \\
& $4-6$ & 43 & 39.1 \\
& $7-10$ & 28 & 25.5 \\
& 10 and above & 12 & 10.9 \\
\hline
\end{tabular}

Source: Authors' Analysis

\subsection{Spatial Pattern of Flooding/Rainstorm incidents in /lorin}

An analysis of the Data obtained from KWEMA office shows that the impacts of the flooding/rainstorm disaster incidents were more in the traditional, core areas of the city going by the number of properties damaged. Figure 3 is a map of Ilorin showing the severity of the disaster incidents between 2002 and 2008. 


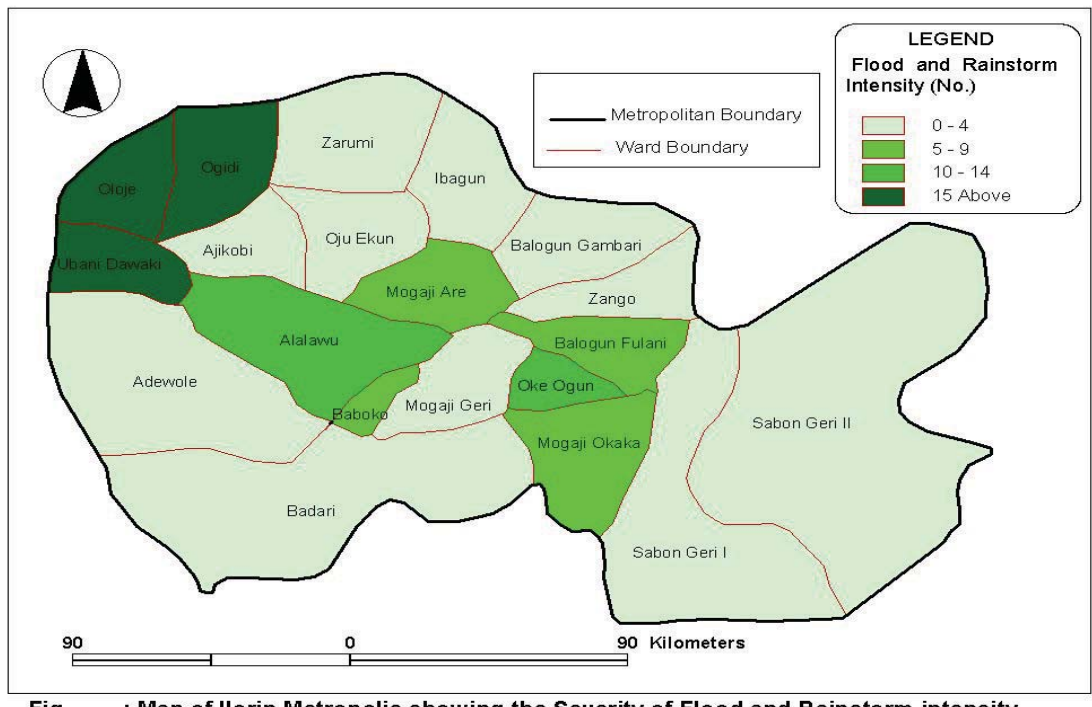

Fig. : Map of Ilorin Metropolis showing the Severity of Flood and Rainstorm intensity.

It should be noted that the traditional, core areas of the city are characterised by high population and the people in these areas are most at risk of all environmental emergencies. This is because basic infrastructures are either not available or old and weak. The houses are also too old or are made of low quality materials. The existing situation has increased the anxiety on the part of the people that future incidents will continue to have higher impacts. The next section which discusses the characteristics of the affected buildings from data collected from the field further confirm the fact that most of the buildings in most parts of the city especially the core, indigenous areas cannot withstands rainstorm or severe flooding whenever they occur.

\subsection{Characteristics of affected Buildings}

The structure of a building directly affects its resistance to rainstorm and flooding, and the houses are not of very good materials. As shown in Table 3, more than half $(60 \%)$ of the houses are more than 30 years of age, more than one third (37.3\%) constructed with mud bricks. About $64.6 \%$ roofed with metal sheets which have turned brownish and fragile over the years. More than two third of the houses have their floor made with earthen floor, out of which about $12.7 \%$ are not plastered at all. The houses are mostly multi family houses (35.5\%). The implication of this is that more people are exposed to risks when ever disasters strike in the area, especially the core/indigenous areas. Poor waste collection system leads to drainage blockage. Drainage channels in the modern parts of the city are not open enough to allow free flow of water during heavy rainfall. In the core, indigenous areas, drainage channels are currently non-existent.

Table 3: Characteristics of affected Buildings

\begin{tabular}{lllll}
\hline \multicolumn{2}{l}{ Characteristics } & & Frequency & Percentage \\
\hline Age of building & $1-10$ & 4 & 3.6 \\
(years) & $11-20$ & 12 & 10.9 \\
& $21-30$ & 28 & 25.5 \\
& $31-40$ & 51 & 46.4 \\
Materials & 42 and above & 15 & 13.7 \\
\hline
\end{tabular}




\begin{tabular}{llll}
\hline External wall & Concrete plates & 3 & 2.7 \\
& Mud bricks & 41 & 37.3 \\
Materials for the & Wood logs & 1 & 0.9 \\
roof & Asbestos sheets & 10 & 9.1 \\
& Metal sheets & 71 & 64.6 \\
\multirow{4}{*}{ Material for the floor } & Tiles & 2 & 1.8 \\
& Mood thatch & 17 & 15.5 \\
& Tile & 12 & 10.9 \\
& Concrete & 18 & 16.4 \\
Type of dwelling & Plastered earthen floor & 66 & 60.1 \\
& Unplastered earthen floor & 14 & 12.7 \\
& Detached house & 10 & 9.1 \\
& Multi family house & 39 & 35.5 \\
& Separate apartment & 7 & 6.4 \\
Nature of ownership & Rooms in a large dwell & 36 & 32.8 \\
& Others & 18 & 16.4 \\
& Owner occupied & 43 & 39.1 \\
& Family owned & 45 & 40.9 \\
& Rented house & 18 & 16.4 \\
\hline
\end{tabular}

Source: Authors' Analysis

The result of the multiple linear regression model tested to see the determinants of the vulnerability to rainstorm and flooding shows that the house characteristics and neighbourhood quality contribute significantly to vulnerability to rainstorm and flooding. The ' $R$ ' value obtained for the model is 0.65 while the $R^{2}$ is 0.43 . This result is interpreted to mean that the independent variables contribute $43 \%$ to the explanation of the determinants of vulnerability of houses to flooding. Furthermore, the unstandardized regression coefficients shows that HTT (age of building) contributed most to this explanation among the independent variables.

\section{Coefficients ${ }^{a}$}

\begin{tabular}{|c|c|c|c|c|c|c|}
\hline \multirow{2}{*}{\multicolumn{2}{|c|}{ Model }} & \multicolumn{2}{|c|}{$\begin{array}{l}\text { Unstandardized } \\
\text { Coefficients }\end{array}$} & \multirow{2}{*}{$\begin{array}{c}\begin{array}{c}\text { Standardized } \\
\text { Coefficients }\end{array} \\
\text { Beta }\end{array}$} & \multirow[b]{2}{*}{$\mathrm{t}$} & \multirow[b]{2}{*}{ Sig. } \\
\hline & & $\mathrm{B}$ & Std. Error & & & \\
\hline \multirow[t]{6}{*}{1} & (Constant) & 6.595 & 6.058 & & 1.089 & .295 \\
\hline & VAR00001 HTT & .251 & .863 & .091 & .291 & .775 \\
\hline & VAR00002 HCB & 5.927E-02 & .494 & .029 & .120 & .906 \\
\hline & VAR00003 HIR & -.592 & .793 & -.201 & -.746 & .468 \\
\hline & VAR00004 DT & 8.001E-02 & .669 & .030 & .120 & .907 \\
\hline & VAR00006 NQ & -6.625 & 2.408 & -.594 & -2.751 & .016 \\
\hline
\end{tabular}

a. Dependent Variable: VAR00007 NHD

\subsection{Impact of Flooding on Livelihood Systems}

Flooding and rainstorm, apart from causing destruction to lives and properties often cause significant damage to livelihood systems of the victims. When asked the various ways by which the flooding and rainstorm disasters have eroded their livelihood systems, pauperisation and health problems appear to be the major dimension. For instance, as lamented by some respondents, the incidents generally caused disruption of electricity in some areas for months affecting trading and crops washed away on farms, especially among those in the suburban. It should be noted that when electricity supply is unavailable for some time, it slows down economic activities among the 
traders and the artisans which, incidentally, constituted the highest proportions of those affected. Furthermore, the disasters are associated with a number of health problems including bodily injuries as well as the attendant psychological trauma. According to one of the victims, "when one's health is affected by disaster incidents, it becomes difficult, if not impossible, to continue with one's means of livelihood". According to him, "this is the singular most worrisome aspect of disaster impact". The post disaster adjustment would have been easier if relief comes from government and non-governmental organisations on time.

A number of women in the inner city and Frontier Native areas depend on irrigated vegetable farming around the flood plains of Asa, Aluko and Amule- the three dominant streams that flow in most parts of the metropolis. During flood events, vegetable farms are washed away and the land remain flooded for a long time after. Women are rendered unemployed for upwards of three months when they can start all over. To worsen this situation, poor urban women's economy is not diversified and thus entrenching the regime of poverty.

\subsection{Coping mechanisms employed by Victims}

Poor communities can be especially vulnerable, in particular those concentrated in high-risk areas. They tend to have more limited adaptive capacities, and are more dependent on climate-sensitive resources such as local water and food supplies (see Satterthwaite et al, 2007). The victims were asked how they coped with the immediate impact of the flooding/rainstorm disaster and the adjustment process. The results presented in Table 4 shows that by and large, support from friends and relatives and personal savings accounted for the way large proportion of the victims cope with the immediate impacts of the disaster. Even though government support came for most of them, many of the victims said the support did not come on time and it did not measure any closer to the degree of impacts suffered by the victims. This calls to question the level of disaster response in Nigeria. It is an accepted fact that the agency charged with disaster management in Nigeria (NEMA) is incapable of responding promptly and managing the various disasters that had occurred in Nigeria in recent years. A major problem has been in the areas of funding and lack of modern equipment to respond to disasters in the country. According to some of the victims, many of them did not get relief materials until after six months especially those that had to do with materials to repair or rebuild damaged properties. The coping mechanisms employed by victims as presented in Table 4.

\section{Table 4: Coping Mechanisms employed by Victims}

\begin{tabular}{|l|l|l|}
\hline & ${ }^{*}$ Frequency & Percent \\
\hline Personal savings & 29 & 23.7 \\
Support from friends and relatives & 50 & 41.0 \\
Borrowing from local money lenders & 11 & 9.0 \\
Borrowing from banks & 6 & 4.9 \\
Government donations & 26 & 21.3 \\
\hline
\end{tabular}

\section{* multiple sources of coping mentioned by respondents}

Source: Authors' Analysis

\subsection{Adaptation measures to Rainstorm and Flooding Disasters}

Given the existing low level of knowledge of victims about climate change issues, it became difficult to elicit information from them on how to adapt to the problems. Interviews with the victims on adaptations measures they would need or are currently using reveals that two broad measures are required. These are the short term and the long term measures. Immediate, short term measures include improvement in the waste collection system and in the core areas, introduction of waste 
collection system to avoid drainage blockage. Secondly, drainage channels in the modern parts of the city have to be opened to allow free flow of water during heavy rainfall. But in the core, indigenous areas, drainage channels would have to be constructed because they are currently nonexistent.

Furthermore, some of the victims especially those who are traders and artisans have decided not to keep too much of their goods in stock during the raining season to avoid heavy losses. Some also have decided to imbibe banking culture by keeping their money in the banks. There is, however, no mention of insurance among the respondents. It's something that is strange to more than $70 \%$ of them.

The long term measures proposed by the victims include reinforcement of the houses in the indigenous areas or complete rebuilding of some of the houses. However, when asked if the victims would be willing to relocate from their present areas especially those in the worse hit areas, many of them said that they have never contemplated such as move. This was especially true among the old.

As easy as some of these adaptation measures may seem, the existing level of poverty may hinder any of such measures. This is why government at the state and local level must come in. government need to put in place measures to reduce the remote factors that exacerbate the intensity and impacts of flooding and rainstorm. Such measures include construction of drainage channels in all parts of the city, improved waste collection system in the city. The government would need to support both the victims and the non victims in reinforcing the existing weak structures in most parts of the city and especially in the indigenous area. But more importantly, there is need for government to enforce building regulations and to improve on city governance.

\section{Conclusion}

This study brings out the important issue of vulnerability, coping and adaptation to disasters caused by extreme weather events among the urban poor. It examined in some detail the strategies adopted by poor neighbourhoods as disasters impact on their livelihood systems and the sequence of responses which they employ over time as they struggle to cope. The study revealed that the indigenous coping mechanisms employed by the poor may become less effective as increasingly fragile livelihood systems struggle to withstand disaster shocks. Also, many of these long-term trends are rendering indigenous coping strategies less and less effective and thus are increasing the vulnerability of the poor.

It seems increasingly accepted (although not consistently implemented) that disasters shouldn't be dealt with through humanitarian relief interventions alone as revealed in this study. There is some evidence to support the argument that disaster management response in the city, just like in other areas in Nigeria, should shift away from this traditional response approach to focus increasingly on addressing the causes of vulnerability in order to mitigate the effects of disaster. However, the approach tends to address only the visible signs of vulnerability, such as poor access to services, and generally fails to make a deeper analysis based on the maintenance of sustainable livelihoods by vulnerable people.

The result of the study is expected to be useful in designing appropriate institutional interventions capable of transiting victims from being painful victims to developing adaptive capacity to live with recurring floods in Nigeria. Most studies indicate, with sufficient evidence, that climate will continue to change with far reaching implications on the environment and human livelihoods. Strategies to reduce vulnerability should be rooted in vulnerability analysis and greater understanding of both household-level and macro response options that are available to decrease the poor's exposure to climate risk. Increasing the response-capability of Nigeria will require information on seasonal forecast to enable the preparedness to climate variability as well as longer term climate prediction data to ensure that strategies to reduce vulnerability also reflect the underlying longer-term climate trends. 


\section{References}

Adedibu, A.A (1980) "Spatial Pattern of Housing Modernisation in the Traditional Area of Ilorin". Nig. Geog. Jour. 23(1-2) 147-161

Adelekan, I.O. (2009) Vulnerability of Poor Urban Coastal Communities to Climate Change in Lagos, Nigeria, Paper presented at the Fifth Urban Research Symposium 2009, Marseille, http://www.urs2009. net/docs/papers/Adelekan.pdf.

Ashley R.M., Blanksby J., Chapman J. \& Zhou J (2007) "Towards integrated approaches to increase resilience and robustness for the prevention and mitigation of flood risk in urban areas". In: R. Ashley, S. Garvin, E. Pasche, A. Vassilopoulos \& C. Zevenbergen, eds. Advances in urban flood management. London: Taylor and Francis, 2007, ISBN: 9780415436625.

Dilley, M., Chen, R.S., Deichmann, U., Lerner-Lam, A., Arnold, M. (2005) "Natural Disaster Hotspots. A Global Risk Analysis". The World Bank, Hazard Management Unit, Washington, DC.

Few, R., H. Osbahr, L.M. Bouwer, D. Viner and F. Sperling (2006) "Linking climate change adaptation and disaster management for sustainable poverty reduction". Synthesis Report for Vulnerability and Adaptation Resource Group (VARG). Available ec.europa.eu/development/icenter/.../env_cc_varg_adaptation_en.pdf

Gbadegesin, A.S., Olorunfemi, F.B. and Raheem, U.A (2011) "Urban Vulnerability to Climate Change and Natural Hazards in Nigeria". In: Hans Günter Brauch, Ursula Oswald Spring, Czeslaw Mesjasz, J ohn Grin, Patricia Kameri-Mbote, Bechir Chourou, Pal Dunay, Jörn Birkmann (Eds.): Coping with Global Environmental Change, Disasters and Security - Threats, Challenges, Vulnerabilities and Risks (Hexagon Book Series on Human and Environmental Security and Peace, Vol. 5. Berlin: SpringerVerlag, 2011), pp 669-688. DOI: 10.1007/978-3-642-17776-7

Heltberg, R., Lau Jorgensen, S.L and Paul Bennett Siegel (2008) "Climate Change, Human Vulnerability, and Social Risk Management" paper was prepared for the Workshop on Social Aspects Of Climate Change, March 5-6, 2008 at the World Bank headquarters in Washington D.C.

Henderson, L.J (2004) "Emergency and Disaster: Pervasive Risk and Public Bureaucracy in Developing Nations". Public Organization Review: A Global Journa/Vol. 4 pp 103-119

Intergovernmental Panel on Climate Change (IPCC) (2001) Climate Change 2001: Impacts, Adaptation, and Vulnerability, summary issue in rural development. Development Policy Review, 19 (4): 507519.

International Strategy for Disaster Reduction (ISDR), (2008) "Disaster Risk Reduction Strategies and Risk Management Practices: Critical Elements for Adaptation to Climate Change" Submission to the UNFCCC Adhoc Working Group on Long Term Cooperative Action. Accessed at: www.unisdr.org/.../risk-reduction/climate-change/.../IASC-ISDR_paper_cC_and_DDR.pdf -

Lemos, Maria Carmen and Emma L Tompkins (2008) "Responding to the risks from climate related Disasters" id $21 \mathrm{~h}$ ig h / ig h t s climate Change (UK: IDS), p3.

Mabogunje, A.L. (1968) Urbanisation in Nigeria. University of London Press.

Mark Davies, Katy Oswald, Tom Mitchell and Thomas Tanner (2008) "Climate Change Adaptation, Disaster Risk Reduction and Social Protection" Briefing Note (UK: Institute of Development studies). Accesses

at: http://www. preventionweb.net/files/7848 IDS20Adaptive20Social20Protection20Briefing20Note201 120December2020081.pdf

Miller, M. (2007) "Adapting to Climate Change: Water Management for Urban Resilience" Environ Urban, $19,99-113$

O’Brien Karen, Linda Sygna, Robin Leichenko, W. N. Adger, Jon Barnett, Tom Mitchell, Lisa Schipper, Thomas Tanner, Coleen Vogel and Colette Mortreux (2008) Disaster Risk Reduction, Climate Change Adaptation and Human Security. Report prepared for the Royal Norwegian Ministry of Foreign Affairs by the Global Environmental Change and Human Security (GECHS) Project, GECHS Report 2008:3.

Oelofse, C. (2002) "Dimensions of Urban Environmental risk" In: Nomdo, C. and Coatzee (Eds): Urban Vulnerability: Perspectives from Southern Africa. Published by Peri Peri Publications. Pp. 28-53. 
Olorunfemi F.B (2008) "Disaster Incidence and Management in Nigeria". Research Review. Vol.24 No. 2, pp $1-23$

Olorunfemi, F.B and Raheem U.A (2007) "Urban Development and Environmental Implications: The Challenge of Urban Sustainability in Nigeria". Ibadan Journal of the Social Sciences. Vol. 6 No 1 (March) pp. 69-78

Pahl-Wostl C. (2006) Framework for adaptive water management regimes and for the transition between regimes. NeWater project, Report Series No. 12, 2006.

Pelling, M. (2008) "The vulnerability of cities to disaster and climate change: A conceptual introduction", in H.G Brauch (ed) Coping with Global Environmental Change, Disasters and Social Security, Springer-Verlag, London.

Satterthwaite David, Saleemul Huq, Mark Pelling, Hannah Reid and Patricia Romero Lankao (2007) "Adapting to Climate Change in Urban Areas The possibilities and constraints in low- and middleincome nations" Human Settlements Discussion Paper Series.

Smit, B., O. Pilifosova, I. Burton, B. Challenger, S. Huq, R. Klein, G. Yohe. (2001) 'Adaptation to climate change in the context of sustainable development and equity.' In J. McCarthy, O. Canziani, N. Leary, D. Dokken, and K. White (eds), Climate Change 2001: Impacts, Adaptation and Vulnerability, Contribution of Working Group II to the Third Assessment Report of the Intergovernmental Panel on Climate Change, Cambridge University Press, Cambridge, UK and New York, USA.

Sz" oll" osi-Nagy A. \& Zevenbergen C., (2005) Urban Flood Management. Rotterdam: A.A. Balkema Publishers, 2005.

Thomas David, Henny Osbahr, Chasca Twyman, Neil Adger and Bruce Hewitson (2005) "ADAPTIVE: Adaptations to climate change amongst natural resource-dependant societies in the developing world: across the Southern African climate gradient". Tyndall Centre for Climate Change Research Technical Report 3

Vogel, C. (2002) A preliminary assessment of environmental vulnerability in Southern Africa. Save the Children UK, South Africa scenario planning paper. 29pp.

Vogel, C., (2000) Usable science: an assessment of long-term seasonal forecasts amongst farmers in rural areas of South Africa, South African Geographical Journal, 82, 107-116.

Zevenbergen, C., W. Veerbeek, B. Gersonius and S. van Herk (2008) "Challenges in urban flood management: traveling across spatial and temporal scales" Journal of Flood Risk Management, Vol. 1, Issue 2, pp 81-88 